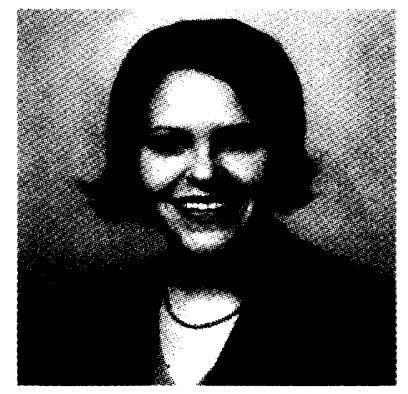

Julie C. Klish

Ms. Klish is an associate specializing in health care and food and drug regulation with the law firm of Hyman, Phelps \& McNamara, P.C. in Washington, DC. In 2004, Ms. Klish graduated from the University of North Carolina School of Law, where she was a member of the North Carolina Law Review. She received a Bachelor of Arts from Purdue University (with Highest Distinction, honors, and Phi Beta Kappa, 2001).

Ms. Klish is a member of the American Bar Association and the Food and Drug Law Institute. In the fall of 2004, her article on group purchasing organizations won second place in the Food and Drug Law Institute's H. Thomas Austern writing competition. She is admitted to practice law in North Carolina and is pending admission to the District of Columbia Bar. 



\title{
SERVING ECONOMIC EFFICIENCIES OR ANTICOMPETITIVE PURPOSES? THE FUTURE OF GROUP PURCHASING ORGANIZATIONS AND THE ANTITRUST SAFETY ZONE
}

\begin{abstract}
Julie C. Klish*
"Gaining a GPO contract is essential for any medical equipment supplier.

GPOs determine which medical devices will be used to treat us when we are sick or injured, which manufacturers will survive and prosper, and-which ones will fail."
\end{abstract}

\section{INTRODUCTION}

While price competition is at the heart of the medical device industry, so too is competition for innovation and product quality. After all, the medical device industry deals primarily in life-saving mechanisms. However, the presence of small research and development companies, which focus primarily on developing better, innovative devices, may be on the decline today due to joint purchasing arrangements used by the group purchasing industry. This article will analyze the antitrust safety zone for group purchasing organizations ("GPOs") and whether this safety zone has become a safe harbor for monopolists. Putting the safety zone aside, this article will identify how current contracting practices utilized in joint purchasing arrangements would constitute antitrust law violations outside of the group purchasing, health care context. After considering the practical effect of current GPO contracting practices on small medical device manufacturers, this article critically examines the government's decision to maintain the status quo of the antitrust safety zone.

* Ms. Klish is an associate at the law firm of Hyman, Phelps \& McNamara, P.C. in Washington, DC (B.A., Purdue University, 2001; J.D., University of North Carolina, 2004). The views expressed in this Article are the views of the author and do not necessarily represent the views of Hyman, Phelps \& McNamara, P.C. or any of its clients. She would like to thank Steven D. Tibbets for his encouragement to publish this Article and her family and friends for their support.

1. Hospital Group Purchasing: Lowering Costs at the Expense of Patient Health and Medical Innovation?, Before Sen. Judiciary Comm. Subcomm. on Antitrust, Competition \& Bus. \& Consumer Rights, 107th Cong. (2002) (statement of Sen. Herbert Kohl, Subcomm. Chairman), available at $\mathrm{http}: / / j u d i c i a r y . s e n a t e . g o v /$ member_statement.cfm? $\mathrm{id}=236 \&$ wit_id $=470$. 


\section{BACKGROUND: GPOS AND CURRENT CONTRACTING PRACTICES}

With approximately 6,900 hospitals nationwide ${ }^{2}$ annually spending an estimated $\$ 190$ billion on supplies, ${ }^{3}$ GPOs intermediate this billion dollar industry by negotiating contracts with hospitals and manufacturers alike. In 2000 , a government-commissioned study showed that "72 percent of all hospital purchases are made via a GPO-negotiated contract."4 For a company that manufactures medical devices, contracting with a GPO is a marketing department's dream. Some of the largest GPOs manage several hundred member hospitals that each desire to purchase the best medical devices for the cheapest price. ${ }^{5}$ GPOs, though intermediaries, wield great power in this position.

GPOs are created through an alliance among health care organizations to aggregate their buying power in order to achieve "advantages of scale." The member health care organizations of the GPO are its owners or affiliates, much like the corporate model. The owners typically hold shares or equitable interests while the affiliates possess only a contractual relationship with the GPO. ${ }^{7}$ All of these entities comprise the membership of a GPO. By negotiating supply contracts for their health care provider members, GPOs help hospitals "eliminate duplicative transaction costs" that each would incur by individually negotiating supply contracts. ${ }^{8}$ GPOs are sophisticated entities that gather information about the latest medical products and finance their

2. U.S. GEN. ACCOUNTING OFFICE, GAO-03-998T, GROUP PURCHASING ORGANIZATIONS: USE OF CONTRACTING PROCESSES AND STRATEGIES TO AWARD CONTRACTS FOR MEDICALSURGERY PRODUCTS 5 (2003) [hereinafter GAO-03-998T].

3. Senate retains grip on GPOs, HEALTHCARE PURCHASING NEWS ONLINE, Nov. 2003,

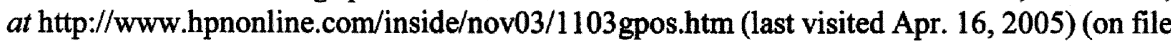
with the Indiana Health Law Review).

4. Group Purchasing Organizations: Fed. Trade Comm. and Dep't of Justice Joint Hearings on Health Care and Competition Law and Policy, at 6 (September 26, 2003) (statement of Robert Betz, Ph.D., President and CEO of Health Industry Purchasing Group Association (HIGPA)) (referencing a March 2000 study conducted by Muse $\&$ Associates), available at $\mathrm{http} / / / \mathrm{www} . \mathrm{ftc}$.gov/os/comments/healthcarecomments2/higpa.pdf.

5. GAO-03-998T, supra note 2, at 4.

6. Premier, MDShareonline: News for Physicians and Healthcare Executives - Frequently Asked Questions, at http://www.premierinc.com//all/mdshare/mdshareonline_FAQs/ FAQ-indexpage-mdshareonline.jsp (last visited Apr. 16, 2005) (on file with Indiana Health Law Review). Premier is the second largest GPO with an estimated 1,800 members. U.S. GEN. ACCOUNTING OfFice, GAO-02-690T, Group Purchasing ORganizations: PILOT Study

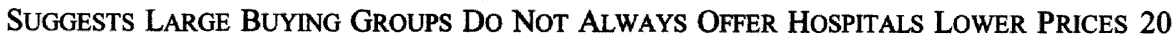
(2002) [hereinafter GAO-02-690T].

7. GAO-02-690T, supra note 6, at 5-7; see Premier, About Premier: Fast Facts, at http://www.premierinc.com/all/aboutpremier/overview/fast-facts.jsp (last visited Apr. 16, 2005) (on file with the Indiana Health Law Review).

8. Thomas H. Brock, Hospitals, Group Purchasing Organizations, and the Antitrust Laws, HEALTHCARE FIN. MGMT., Mar. 2003, at http://www.findarticles.com/cf_dls/m3257/ 3_57/98953926/print.jhtml (last visited Apr. 16, 2005) (on file with the Indiana Health Law Review). 
own independent tests of new products, which are functions that, practically speaking, "no one provider could finance or conduct."

For example, Novation, the largest of the GPOs with an estimated 2,300 members, was formed in 1998 after two alliances consolidated their supplycontracting areas. ${ }^{10}$ Novation facilitates roughly $\$ 23$ billion in annual purchases by its members. ${ }^{11}$ While Novation is the largest GPO, the government estimates that there are several hundred GPOs, though seven of these GPOs "account for more than 85 percent of all hospital purchases nationwide made through GPO contracts."

Membership in a GPO is voluntary to the extent that a health care provider can afford the expense of directly contracting for its supplies with individual manufacturers and distributors. There are several different membership arrangements that GPOs can have with their members. For those health care providers who join a GPO, some GPOs, such as HealthTrust, prohibit membership in other GPOs. ${ }^{13}$ In addition, GPOs often require that their members purchase all of their supplies or a percentage of their supplies through GPO negotiated contracts. ${ }^{14}$ Overall, GPOs vary widely in the membership requirements and restrictions that they impose.

The main function of GPOs is to negotiate contracts with manufacturers and distributors of supplies that their health provider members need in order to operate. The agreements that GPOs negotiate with suppliers utilize various contracting mechanisms, which include the signing of product bundling, solesource, long-term, and requirements contracts each of which charges administrative fees to manufacturers. The General Accounting Office (GAO) discussed each of these in its July 16, 2003 report to the Senate Subcommittee on Antitrust, Competition Policy and Consumer Rights. ${ }^{15}$ After a brief description of each contracting practice, the remainder of this article will center on an analysis of whether these contracting practices would violate the federal antitrust laws if used outside the group purchasing arena. ${ }^{16}$

9. Id.

10. Novation, About Novation: Overview, at http://www.novationco.com/about/ default.asp (last visited Apr. 16, 2005) (on file with the Indiana Health Law Review).

11. Id.

12. GAO-03-998T, supra note 2, at 4. The majority of GPOs are regional or local; however, the majority holders of purchasing volume are the seven national GPOs. The seven largest GPOs in descending order are: Novation, Premier, AmeriNet, HealthTrust, InSource, Consorta, Broadlane, and HPPI. GAO-O2-690T, supra note 6, at 20-22.

13. GAO-02-690T, supra note 6, at 6.

14. GAO-03-998T, supra note 2, at 12-13.

15. Id. at $10-14$.

16. 15 U.S.C. $\S \S 1,2,14(2005)$. 


\section{CONTRACTING Practices}

Product bundling refers to the practice of grouping together multiple products and selling them to GPO members as a package deal. GPOs use these bundling arrangements in three varieties: bundling "complementary products," requirements bundling ${ }^{19}$ from different manufacturers. ${ }^{20}$ The appeal of bundling from the customer's perspective is a discounted price for items purchased in a bundle rather than separately through the GPO. The appeal of bundling from the manufacturers' perspective is an increased likelihood that their products will be purchased, which justifies the price reduction on their end.

The practice of sole-sourcing is used by GPOs when they contract with only one manufacturer to supply that type of device or product to their members, thereby establishing an exclusive dealing contract with that manufacturer. Customers of the GPO are then given one choice for obtaining that medical device or product through the GPO. For GPOs that require members to purchase all of their supplies from those manufacturers with whom the GPO has negotiated contracts, this contracting mechanism guarantees sales for the manufacturer who is awarded a sole-source contract.

GPOs also sign long-term contracts with medical device manufacturers and commitment agreements with GPO members. After evaluating the seven largest GPOs, the GAO reported that the "two largest GPOs typically awarded 5-year contracts, whereas the other five GPOs typically awarded 3-year contracts." 21 These agreements ensure the likelihood of future sales for manufacturers and reduce the frequency in which GPOs have to renegotiate contracts with manufacturers. Commitment agreements, on the other hand, require GPO customers to buy a certain amount or percentage of their supplies from manufacturers who have contracted with the GPO. The commitment levels assist GPOs in negotiating contracts with manufacturers, because the manufacturers are more willing to offer a discounted price where commitment levels ensure sales.

Finally, GPOs charge each manufacturer administrative fees based on the total purchases that members of the GPO make from the manufacturer. A provision of the Social Security Act permits GPOs to charge and receive administrative fees as an exception to the anti-kickback rules. ${ }^{22} \mathrm{~A}$ Department

17. GAO-03-998T, supra note 2, at 6 (providing an example of protective hats and shoe coverings as complementary products).

18. The GAO refers to this type of bundling as a "corporate agreement." Id. at 13.

19. The GAO refers to this type of bundling as a "structured commitment program." Id. This type of bundling groups products from different manufacturers together to form a package deal and additionally requires customers to agree to purchase a set percentage of their total requirements from the bundle.

20. Id.

21. Id. at 14.

22. 42 U.S.C $\S 1320 \mathrm{a}-7 \mathrm{~b}(\mathrm{~b})(3)(C)(2005)$. 
of Health and Human Services regulation strengthens the Social Security Act's writing requirement on administrative fees by requiring GPOs to limit fees to a maximum of $3 \%$ of the purchases made under the contract or to stipulate some other amount up front. ${ }^{23}$ The use of disjunctive language in this regulation allows GPOs to name their price so long as manufacturers agree to pay the fees set by the GPO. The GAO reported that the highest fee charged by the GPOs that it studied was around $18 \%{ }^{24}$

Over the last few years, this array of contracting practices has undergone the scrutiny of the U.S. Senate, Department of Justice ("DOJ"), and Federal Trade Commission ("FTC"). GPOs represent the buyers in the health care industry and try to negotiate the best deal for those buyers. On the other hand, most GPOs are for-profit entities with operation costs and have an interest in negotiating contracts that will minimize their costs (and maximize their profits). In their role as intermediaries, there is no question that GPOs have administratively made the hospital supply contracting process more efficient. ${ }^{25}$ But are the contracting practices that GPOs use assisting a handful of manufacturers in monopolizing product markets within the medical device industry under the guise of efficiency?

\section{THE PROTECTION OF THE SAFETY ZONE}

In 1993, the DOJ and FTC first issued an antitrust enforcement policy for joint purchasing organizations that was later revised in 1996. That policy, as it reads today, creates a safety zone from antitrust enforcement for GPOs that satisfy a two-part test. In other words, the safety zone exempts GPOs from antitrust enforcement, provided that they can meet the requirements of the test. The DOJ and FTC have said that they "will not challenge, absent extraordinary circumstances, any joint purchasing arrangement among health care providers" that satisfies the two-part test. ${ }^{26}$

The first hurdle established by the two-part test requires a GPO to show that "the purchases account for less than 35 percent of the total sales of the purchased product or service in the relevant market." ${ }^{27}$ For example, this means that the total pacemaker purchases made by members of an individual GPO cannot exceed a percent threshold when compared to the total amount

23. 42 C.F.R. $\S 1001.952(j)(2005)$.

24. GAO-03-998T, supra note 2 , at 10.

25. The cost-benefit analysis remains fuzzy, however, following the release of the GAO report which suggested, based on a sampling of medical products studied, that large GPOs are not producing savings for their member providers that are greater than what small GPOs or providers individually have been able to negotiate. GAO-02-690T, supra note 6, at 3 .

26. U.S. DEP'T OF JUSTICE \& FED. TRADE COMM., Statement of Department of Justice and Federal Trade Commission Enforcement Policy on Joint Purchasing Arrangements Among Healthcare Providers, in STATEMENTS OF ANTITRUST ENFORCEMENT POLICY IN HEALTHCARE 53, 54 (Aug. 1996), available at http://www.ftc.gov/reports/hlth3s.pdf.

27. Id. at 54-55. 
of pacemakers being sold "in the relevant market." ${ }^{28}$ The market is defined two ways, by taking into consideration both a geographic market and a product market. The geographic market for medical devices is generally a national market while the product market can vary depending on the type of medical device. The product market for pacemakers may simply be all pacemakers or it may be a sub-category of pacemakers.

The second requirement is applicable only where some or all of the GPO's member providers are "direct competitors." 29 To satisfy the second prong of the test, the GPO must show that "the cost of the products and services purchased jointly accounts for less than 20 percent of the total revenues from all products or services sold by each competing participant in the joint purchasing arrangement." ${ }^{30}$ This means that the aggregated purchases made by the GPO's members cannot exceed $20 \%$ of the total profits made from all goods and services sold by each competing member provider.

In 1994, Thomas Greaney, an antitrust scholar, explained the government's reasoning behind this two-part test. He stated:

The logic of this analysis is that unless the [GPO] ... represents a significant proportion of all buyers in the market, it probably cannot exercise monopsony power to drive prices of purchased goods or services below competitive levels. Thus, any lower prices negotiated likely reflect efficiency benefits, such as economies of scale. ${ }^{31}$

If providers' joint purchasing arrangements fall within the safety zone, then they are exempt from antitrust enforcement and the agencies will only challenge their arrangement in "extraordinary circumstances." ${ }^{32}$ However, this phrase has never been defined by the agencies, so it is an unknown standard.

One major shortcoming of the joint purchasing safety zone is that it provides "no guidance for enforcement policy on exclusionary agreements that GPOs might enter into with suppliers." 33 The agencies do provide a list of three mitigating factors to consider for arrangements that fall outside the safety zone; however, these factors are not considered for arrangements that fall inside the safety zone. In their enforcement policy, the agencies state that "antitrust concern is lessened" where: (1) "members are not required to use

28. $I d$. at 55 .

29. Id.

30. Id.

31. Thomas L. Greaney, A Critique: The Department of Justice/FTC Health Care Policy Statements, 8 ANTITRUST 20, 22 (1994).

32. U.S. DEP'T OF JUSTICE \& FED. TRADE COMM., supra note 26, at 54.

33. Einer Elhauge, Antitrust Analysis of GPO Exclusionary Agreements: Comments Regarding Hearings on Health Care and Competition Law and Policy-Statement For DOJ-FTC Hearing on GPOs 1 (Sept. 26, 2003), available at http://www.ftc.gov/os/comments/ healthcarecomments $2 /$ elhauge.pdf. 
the arrangement for all their purchases of a particular product or service," (2) an independent employee or agent conducts negotiations for the GPO, and (3) "communications between the purchasing group and each individual participant are kept confidential" from the other participants. ${ }^{34}$

Even where mitigating factors are not present, the agencies state that "[w]here there appear to be significant efficiencies from a joint purchasing arrangement, the Agencies will not challenge the arrangement absent substantial risk of anticompetitive effects." 35 Through the creation of this safety zone, the agencies are tolerating and thereby giving protection to anticompetitive practices used by GPOs as long as the GPOs can meet the requirements of the two-part test and not fall within the undefined "extraordinary circumstances" zone. If the safety zone is met, efficiency and competitive practices are presumed and are only questioned where a GPO cannot meet the requirements of the two-part test.

\section{CONFRONTING THE ANTITRUST LAWS}

Putting the antitrust safety zone aside, this section examines whether the contracting practices used by GPOs could survive restraint of trade, monopolization, and exclusive dealing claims brought under the federal antitrust laws. The would-be plaintiff for this analysis is a small medical device manufacturer, such as Applied Medical Resources Corporation (hereafter "Applied Medical"), that is suing a competitor manufacturer for its use of anticompetitive contracting practices. These anticompetitive practices include product bundling or tying arrangements and exclusive dealing arrangements.

Said Hilal, CEO of Applied Medical, testified in 2003 during the FTC/ DOJ hearings on GPOs. Applied Medical is a corporation with five hundred employees that markets 250 devices used in "Cardiac and Vascular Surgery, General Surgery, Urology, Colorectal Surgery and OBGYN Surgery."36 While Applied Medical does not struggle with the innovation of new devices, it has encountered difficulty marketing its products.

Among the devices that Applied Medical markets are trocars, a basic instrument used to explore tissues. ${ }^{37}$ In his testimony at the FTC/DOJ hearings on GPOs, Mr. Hilal approximated that this is a $\$ 300$ million market. $^{38}$

34. U.S. DEP'T OF JUSTICE \& FED. TRADE COMM., supra note 26, at 56-57.

35. Id. at 57 (emphasis added).

36. Applied Medical, Products, at http://www.appliedmed.com/products/default.aspx (last visited Apr. 16, 2005) (on file with the Indiana Health Law Review).

37. Websters Online Dictionary, Trocar, at http://www.websters-onlinedictionary.org/Tr/Trocar.html (last visited Apr. 16, 2005) (on file with the Indiana Health Law Review).

38. Joint FTC/DOJ Hearings on HealthCare and Competition Law and Policy, Before the Fed. Trade Comm., at 142 (Sept. 26, 2003) (statement of Said Hilal, Chief Executive Officer, Applied Medical Resources Corporation), available at http://www.ftc.gov/ogc/ healthcarehearings/030926ftctrans.pdf. 
After approaching forty GPOs to sell its trocars at a price $60 \%$ below the prices for which the GPOs had contracted with Applied Medical's competitors, none of the GPOs offered Applied Medical contracts. ${ }^{39}$ The reason that Mr. Hilal gives for this is that "[a] handful of GPOs can control 80 percent of the demand channel, and ... [ [o]ne supplier can require 90 percent compliance." ${ }^{40}$ When you imagine that this supplier has contracted, using a $90 \%$ compliance requirement, with the handful of GPOs that Mr. Hilal refers to, then that means that this single supplier controls at least $72 \%$ of the market share for trocars. ${ }^{41}$ According to the United States Court of Appeals, Eighth Circuit, "[a]n eighty percent market share is within the permissible range from which an inference of monopoly power can be drawn." ${ }^{42}$ So, the $72 \%$ market equation, when played out in reality, would likely amount to a finding of monopoly power.

Could a plaintiff such as Applied Medical succeed on restraint of trade, monopoly, or exclusive dealing actions against its competitor manufacturers who have used tying arrangements and exclusive dealing provisions in their contracts? In other words, have courts found similar contracting practices used outside the group purchasing context to be in violation of the federal antitrust laws? In order to allege these claims, a plaintiff must first prove standing to bring such actions. A plaintiff has standing to sue in an antitrust lawsuit provided that the plaintiff manufacturer is able to allege harm and the court finds that this manufacturer, Applied Medical, is a proper plaintiff to bring the antitrust claims. ${ }^{43}$

39. Id.

40. Id. at 143. Mr. Hilal refers to this arrangement as "monopoly multiple." Id.

41. Id.

42. Morgenstern v. Wilson, 29 F.3d 1291, 1296 n.3 (8th Cir. 1994).

43. Associated Gen. Contractors of Cal., Inc. v. Cal. State Council of Carpenters, 459 U.S. 519, 535 n.31 (1983).

As commentators have observed, the focus of the doctrine of 'antitrust standing' is somewhat different from that of standing as a constitutional doctrine. Harm to the antitrust plaintiff is sufficient to satisfy the constitutional standing requirement of injury in fact, but the court must make a further determination whether the plaintiff is a proper party to bring a private antitrust action.

Id. (citing Daniel Berger \& Roger Bernstein, An Analytical Framework for Antitrust Standing, 86 Yale L.J. 809, 813 n.11 (1977)). 


\section{A. Tying Arrangements}

Tying arrangements come under the purview of the restraint of trade rules of the Sherman Act. ${ }^{44}$ The Supreme Court has said:

[T] he essential characteristic of an invalid tying arrangement lies in the seller's exploitation of its control over the tying product to force the buyer into the purchase of a tied product that the buyer either did not want at all, or might have preferred to purchase elsewhere on different terms. When such "forcing" is present, competition on the merits for the tied item is restrained and the Sherman Act is violated. ${ }^{45}$

Under these conditions, tying arrangements are per se unreasonable restraints of trade.

There are five elements that a plaintiff must show to prove the existence of an illegal tie-in arrangement. First, the plaintiff must show the existence of a tying product and a tied product. ${ }^{46}$ The tying product is the one whose sale is conditioned on the requirement that the buyer also purchase the tied product. Second, the plaintiff must produce evidence of "actual coercion by the seller forcing the buyer to accept the tied product." ${ }^{47}$ Third, the plaintiff must show "sufficient economic power in the tying market to coerce" purchasers to buy the tied product. ${ }^{48}$ Fourth, the plaintiff must show "anticompetitive effects in the market for the tied product." ${ }^{" 49}$ Finally, the plaintiff must show the tied product's involvement in a "not insubstantial" amount of interstate commerce. ${ }^{50}$ Where the plaintiff cannot show a per se violation,

44. 15 U.S.C. $\S 1$ (2005). Section 1 of the Sherman Act makes contracts in restraint of trade illegal. There are three elements that a plaintiff must show in order for a section 1 claim to succeed. First, the plaintiff must show that there has been a contract or conspiracy between two parties. Second, the plaintiff must show that this contract or conspiracy "is in, or substantially affects, interstate commerce." Medical Supply Chain, Inc. v. US Bancorp, NA, No. Civ. A.02-2539-CM, 2003 WL 21479192, at *2 (D. Kan. June 16, 2003) (citations omitted). Finally, the plaintiff must show that the contract "unreasonably restrains trade" under either the per se approach or the rule of reason approach. Id. The basic difference between the two approaches lies in the extent to which a court must examine the actual effect on competition which an allegedly anti-competitive business practice has. "Under the rule of reason test, the court must determine the competitive impact of a particular practice in the context of a relevant market. Under the per se rule, a court does not conduct this extensive inquiry, because the practice in question has been held to be manifestly anti-competitive." Ortho Diagnostic Sys., Inc. v. Abbott Labs., Inc., 822 F. Supp. 145, 157 (S.D.N.Y. 1993).

45. Jefferson Parish Hosp. Dist. No. 2 v. Hyde, 466 U.S. 2, 12 (1984).

46. Ortho Diagnostic Sys, Inc., 822 F. Supp. at 157 (quoting Suburban Propane v. Proctor Gas, Inc., 953 F.2d 780, 788 (2d Cir. 1992)).

47. Id.

48. Id.

49. Id.

50. Id. 
courts will apply a rule of reason analysis, examining the particular facts to see if the general requirements for a section 1 claim under the Sherman Act are present. ${ }^{51}$

In 2003, the GAO reported that "most GPOs used some form of bundling, and the two largest GPOs used either contracts or programs that bundled multiple products for a notable portion of their business." ${ }^{52}$ Without the safety zone, a manufacturer like Applied Medical could succeed in a lawsuit against a competitor supplier who has entered into bundling agreements on the grounds that the bundling agreements are per se illegal tying, creating an unreasonable restraint on trade. Because the manufacturers have direct clauses in their agreements with GPOs to bundle products, it would be easy for Applied Medical to prove the first two elements of the tying claim and to show that the sale of trocars affects interstate commerce.

There are only two elements that will present a challenge for Applied Medical. They would need to show that their competitor manufacturer has sufficient power in the tying market in order to coerce customers to purchase the competitor's trocars, which, as a result, has produced anticompetitive effects in the market for trocars. Sufficient power in the tying market is "inferred from the seller's possession of a predominant share of the market." ${ }^{53}$

Determining whether Applied Medical will be able to succeed on this claim will depend on the tying market of their competitor manufacturers. If Applied Medical could demonstrate that a manufacturer held a $72 \%$ market share, which Mr. Hilal presented at the hearings, in the tying product, then this would likely satisfy the requirement of demonstrating power in the tying market. Applied Medical would be able to present the contracts for trocars that customers rejected in order to show anticompetitive effects in the tied, trocar market. There are many cases in the health care area involving tying arrangements, which suggest that the bundling arrangements that manufacturers use with GPOs would be illegal outside the group purchasing context.

In SmithKline Corporation v. Eli Lilly \& Company, ${ }^{54}$ the plaintiff, SmithKline, claimed that Eli Lilly used a pricing scheme that utilized rebates to tie together the purchase of two patented drugs with the purchase of an unpatented drug that Eli Lilly was marketing. ${ }^{55}$ There was no express tying clause forced upon the purchasers; instead, the combination of the patents and rebate system left purchasers no other rational choice than to buy the tied drug. Because of their patents in the tying market, Eli Lilly was in a position to exert coercion over the tied product's market. In this case, the Third Circuit ruled for the plaintiff on a monopoly theory rather than a tying theory, finding

51. See e.g., Arizona v. Maricopa County Medical Soc., 457 U.S. 332, 343-44 (1982).

52. GAO-03-998T, supra note 2, at 11.

53. Eastman Kodak Co. v. Image Technical Servs., Inc., 504 U.S. 451, 464 (1992) (citing Jefferson Parish Hosp. Dist. No. 2 v. Hyde, 466 U.S. 2, 17 (1984)).

54. SmithKline Corp. v. Eli Lilly \& Co., 575 F.2d 1056 (3d Cir. 1978).

55. SmithKline Corp. v. Eli Lilly \& Co., 427 F. Supp. 1089, 1091-92 (E.D. Pa. 1976). 
that Eli Lilly had willfully acquired and unlawfully maintained a monopoly. ${ }^{56}$ If Eli Lilly did not have patents on the drugs to which they were tying, this case probably would have succeeded on a tying theory rather than a monopoly theory.

In Ortho Diagnostic, a contract with the Council of Community Blood Centers (CCBC) was at issue. Ortho Diagnostic Systems, Inc. (hereinafter "Ortho"), the plaintiff, brought this lawsuit against Abbott Laboratories, Inc. for a preliminary injunction alleging an implied tying arrangement similar to the one in SmithKline. ${ }^{57}$ CCBC solicited proposals for five blood screening tests from both the plaintiff and the defendant in the case. Blood donation centers rely on the use of these screening tests to make sure that the blood units that they collect are safe for transfusions. The contract with CCBC was a group purchasing agreement in which blood donation centers had the option of participating. ${ }^{58}$

Abbott won the contract, and Ortho brought suit claiming that Abbott's pricing scheme was a per se unreasonable restraint of trade. ${ }^{59}$ Abbott's HIV and $\mathrm{HTLV}^{60}$ tests were already popular on the market, so Ortho claimed that Abbott used a pricing scheme to force a buyer who wanted those two tests into purchasing the other three. ${ }^{61}$ The District Court held that Abbott's pricing scheme did not violate the Sherman Act and granted summary judgment to Abbott on Ortho's claim of illegal tying with respect to the tests. ${ }^{62}$

At trial, Ortho lost their tying claim, because they failed to show that the pricing scheme used by Abbott made purchasing all five tests from Abbott the "only viable economic option." ${ }^{63}$ Furthermore, the court found that "if the tying product may be purchased without also buying the allegedly tied product, there can be no unlawful tying." ${ }^{64}$ It is worth pointing out that this case was decided when the safety zone for GPOs was in place. The court did not pay any special attention to the fact that $\mathrm{CCBC}$ was negotiating a group purchasing contract in this case.

Applying both of these cases to the bundling arrangements that GPOs have admitted to using, it is clear that without the antitrust safety zone, the

56. SmithKline Corp., 575 F.2d at 1065.

57. Ortho Diagnostic Sys., Inc. v. Abbott Labs., Inc., 822 F. Supp. 145, 147 (S.D.N.Y. 1993). In this case, there was not an explicit condition in the contract with CCBC that required buyers of the HIV and HTLV tests to purchase the other three tests from Abbott. Id. The court highlighted case law that suggests that a tying arrangement can be "inferred from the pricing structure of two products and the market power which the party has." Id. at 157-58.

58. Id. at 148-49.

59. Id. at 157.

60. This is a test used to detect a type of leukemia. Id. at 147 .

61. Id. at 157. 1996).

62. Ortho Diagnostic Sys., Inc. v. Abbott Labs., Inc., 920 F. Supp. 455, 477 (S.D.N.Y.

63. Id. at $471-72$.

64. Id. at 471 . 
parties to joint purchasing bundling arrangements would be violating the Sherman Act's provision against unreasonable restraints of trade. The manufacturers' contracts with the GPOs directly force member providers to purchase tied products or a high percentage of those tied products; thus, no inference of a tying arrangement is necessary.

Recently, a small medical device manufacturer, similar to Applied Medical, filed a case to challenge a tying arrangement that harmed its sales. In November of 2003, CONMED Corporation, a medical device designer and manufacturer, filed a lawsuit ${ }^{65}$ against Johnson \& Johnson and some of its subsidiaries. The lawsuit alleges that Johnson \& Johnson uses exclusive dealing provisions and the illegal tying and bundling of sutures to high requirements agreements for the purchase of endoscopy products, which penalize hospitals that fail to meet the high requirement levels. ${ }^{66}$ CONMED asserts that "Johnson \& Johnson furthered this anticompetitive conduct through its contracts and other dealings with group purchasing organizations, such as Novation and Premier."67 As a result, CONMED claims that its sales of endoscopic surgical products have been hindered. Furthermore, CONMED argues that Johnson \& Johnson's anticompetitive use of tying arrangements has prevented hospitals from being able to purchase cheaper medical devices, such as those that CONMED markets. ${ }^{68}$

The claims raised by CONMED are similar to the arguments that $\mathrm{Mr}$. Hilal made at the FTC/DOJ hearings with regard to how Applied Medical marketed the same trocars as its competitors at a $60 \%$ price reduction and still was unable to secure contracts. However, it is interesting that CONMED even mentions Johnson \& Johnson's contracts with GPOs in its complaint, since joint purchasing arrangements are generally free from antitrust enforcement through the safety zone. If this case goes forward and does not settle, then it will be interesting to see how the court treats CONMED's claims, given that Johnson \& Johnson enters into these arrangements with both GPOs and individual hospitals.

\section{B. Monopolization}

Section 2 of the Sherman Act makes it a felony to monopolize or attempt to monopolize "any part of the trade or commerce among the several States." 69

65. This lawsuit was filed in the Southern District of New York. CONMED Corporation is headquartered in Utica, New York.

66. CONMED Files Suit Against Johnson \& Johnson for Violation of Antitrust Laws, PR NEwSWIRE, Nov. 10, 2003, at http://www.prnewswire.com/cgibin/stories.pl?ACCT $=104 \&$ STORY $=/$ www/story/11-10-2003/0002054256\&EDATE $=$ (last visited Apr. 16, 2005) (on file with the Indiana Health Law Review).

67. Id.

68. Id.

69. 15 U.S.C. $\S 2$ (2005). 
"Monopoly power is the power to control prices or to exclude competition." The claim of monopoly under section 2 has two elements. First, the plaintiff must show that the defendant possesses monopoly power in the relevant market. Second, the plaintiff must show that the defendant has willfully acquired or maintained that power "as distinguished from growth or development as a consequence of a superior product, business acumen, or historic accident."71 A plaintiff must show the presence of four elements to succeed on an attempted monopolization claim. First, the plaintiff must define the relevant market, including the product and geographic markets. Second, the plaintiff must show that there is a "dangerous probability of success in monopolizing the relevant market." 72 Third, the plaintiff must prove that the defendant had a specific intent to monopolize. ${ }^{73}$ Finally, the plaintiff must show conduct in furtherance of an attempt to monopolize. ${ }^{74}$

Claims of monopolization have been more numerous before the courts than alleged tying arrangements (presumably because of the per se illegality of these). It is much easier to mask unlawfully rising to monopoly power or attempted monopolization than it is to mask a bundling or tying arrangement. A plaintiff, such as Applied Medical, would be able to argue the presence of sole-source and requirements contracts used by its competitor manufacturer in order to demonstrate how its competitor is attempting to obtain monopoly power or has already succeeded in holding monopoly power.

The intent requirement for both actual monopolization and attempted monopolization will be an important factor for the courts. "Unlike the offense of actual monopolization, which requires only a showing of the monopolist's intent to engage in anticompetitive conduct, an allegation of attempt to monopolize cannot succeed unless the would-be monopolist is shown to have 'a specific intent to destroy competition or build monopoly." 75 Outside of the group purchasing context, the long-term, exclusionary agreements that device manufacturers enter into would seem to, by themselves, establish a specific intent to put their competitors out of business. However, malicious intent and vociferous threats to sell at higher prices are behavior "not condemned by Sherman Act section 2" unless these acts in some way contribute to the likelihood that one party will secure a monopoly. ${ }^{76}$

70. Barr Labs., Inc. v. Abbott Labs., 978 F.2d 98, 111-12 (3d Cir. 1992)(citing Pa. Dental Ass'n v. Medical Serv. Ass'n of Pa., 745 F.2d 248, 260 (3d Cir. 1984)).

71. United States v. Grinnell Corp., 384 U.S. 563, 570-71 (1966).

72. Medical Supply Chain, Inc. v. U.S. Bancorp, NA, No.Civ.A. 02-2539-CM, 2003 WL 21479192, at *5 (D. Kan. June 16, 2003) (quoting Full Draw Prods. v. Easton Sports, Inc., 182 F.3d 745, 756 (10th Cir. 1999).

73. $I d$.

74. Id.

75. Ashkanazy v. Rokeach \& Sons, Inc., 757 F.Supp. 1527, 1535 (N.D. Ill. 1991) (quoting Times-Picayune Pub. Co. v. United States, 345 U.S. 594, 626 (1953)).

76. Id. at 1540 . 
In order to succeed on a claim of actual monopolization, as compared with attempted monopolization, the courts primarily focus on the percentage of market share held by the defendant. ${ }^{77}$ In Morganstern $v$. Wilson, the court considers a monopoly challenge by a doctor against a professional corporation of doctors in the same region. ${ }^{78}$ The doctor in that case presented insufficient evidence of the geographic and product markets; however, the court gave an important accounting of the level of market share that would have been sufficient to prove the existence of monopoly power. ${ }^{79}$ The court stated that $80 \%$ is enough, but that " $a$ thirty percent market share will not prove the existence of monopoly power." $"$ The court also cited a case that said $60 \%$ is unlikely sufficient. ${ }^{81}$

But what about the $72 \%$ market share that Mr. Hilal hypothesized a supplier in the market today easily could obtain with the help of GPO contracts? It is unclear, without knowing specific factual circumstances, whether or not courts would generally find this percentage to meet the threshold of monopoly power. What action can a plaintiff like Applied Medical bring when there are two or three manufacturers that have independently bound over $90 \%$ of the market share in long-term, exclusionary agreements? Under these facts, which probably are closer to reflecting market realities, those two or three competitor manufacturers would not be monopolists, unless they were acting together to monopolize the market, and Applied Medical would be left to struggle in a virtually closed market. ${ }^{82}$

The market for erythromycin in the Barr Laboratories case reflects this type of situation, where Abbott Laboratories controlled $50 \%$ of the market, Boots/Upjohn controlled $17.67 \%$ of the market, and Parke-Davis controlled $13.68 \%{ }^{83}$ Together, these three entities held a monopolist's share of the market with a combined $82.17 \%$ of the market. ${ }^{84}$ According to the court, Barr Laboratories asserted that this was a "highly concentrated market." ever, the court concluded that Abbott "did not have a reasonable probability of successfully monopolizing the adult oral erythromycin market." ${ }^{86}$ For

77. In an attempted monopolization case, a manufacturer may hold as high as $50 \%$ of the market share. If the manufacturer is not engaging in activities that tend to lead toward monopolization and thereby lacks the "dangerous probability of success" in attempting to monopolize, the amount of market share is of little relevance. Barr Labs., Inc. v. Abbott Labs., 978 F.2d 98, 112 (3d Cir. 1992).

78. Morganstern v. Wilson, 29 F.3d 1291, 1296 n.3 (8th Cir. 1994).

79. Id. at 1297.

80. Id. at $1296 \mathrm{n} .3$.

81. Id. (citing Domed Stadium Hotel, Inc. v. Holiday Inns, Inc., 732 F.2d 480, 489 (5th Cir. 1984)).

82. However, an exclusive dealing claim might be available, which the next Part of the article will consider.

83. Barr Labs., Inc. v. Abbott Labs., 978 F.2d 98, 112 (3d Cir. 1992).

84. Id.

85. Id. at 113 .

86. Id. 
GPOs with these same levels of market share, the joint purchasing safety zone prevents the antitrust laws from reigning in manufacturers who actually monopolize, or attempt to monopolize, by securing GPO contracts. The safety zone gives manufacturers, the sellers, dangerous freedom in this regard.

The FTC has been active in preventing monopolies from forming in the medical device area. In 2000, the FTC intervened in the proposed acquisition of Mallinckrodt Inc. ("Mallinckrodt") by Tyco International Ltd. ("Tyco") in order to protect competition in the endotracheal tube market. ${ }^{87}$ At the time of the proposed acquisition, Tyco and Mallinckrodt were the two largest suppliers of endotracheal tubes, with Mallinckrodt being the largest. ${ }^{88}$ The FTC's $^{\text {Th }}$ consent decree required Tyco to divest itself of a line of endotracheal tubes, because Tyco's acquisition of Mallinckrodt would give Tyco a postacquisition market share of $86 \%{ }^{89}$ The FTC found this to be a monopolist's share that would allow the combined entity to "exercise market power unilaterally, thereby increasing the likelihood that purchasers of endotracheal tubes would be forced to pay higher prices and that innovation and service levels in the market would decrease." 90 Because the medical device industry involves competition for life-saving devices, the fear of hampering innovation is magnified. Even more important than ensuring a competitive marketplace for medical devices is ensuring a marketplace that permits innovators freely to enter the market.

In March of 2003, the Third Circuit heard a case involving 3M, which conceded that it possessed monopoly power in the transparent tape market by holding a $90 \%$ market share. ${ }^{91}$ LePage's, the plaintiff in the case, argued that " $3 \mathrm{M}$ willfully maintained its monopoly in the transparent tape market through exclusionary conduct, primarily by bundling its rebates and entering into contracts that expressly or effectively required dealing virtually exclusively with 3M . . ..92 In Lepage's, Inc., the Third Circuit reviewed a jury finding that $3 \mathrm{M}$ violated section 2 of the Sherman Act to determine whether there were enough facts in the case to support the jury's finding. ${ }^{93}$ The Third Circuit upheld the jury determination that $3 \mathrm{M}$ violated section 2 . $3 \mathrm{M}$ offered purchasers "magnified rebates" for purchasing 3M's Scotch tape in combination with its other product lines. ${ }^{94}$ The rebates that $3 \mathrm{M}$ gave to LePage's customers were equal to almost half the amount of total sales that LePage's had made to those same customers. ${ }^{95}$ For example, LePage's 1993 sales to Sam's Club

87. Tyco International, Ltd.; Analysis to Aid Public Comment, 65 Fed. Reg. 63,253, 63,253-54 (Oct. 23, 2000).

88. Id at 63,253 .

89. Id. at $63,253-54$.

90. Id. at 63,253 (emphasis added).

91. LePage's, Inc. v. 3M, 324 F.3d 141, 146 (3d Cir. 2003).

92. Id. at 147.

93. Id. at 169 .

94. Id. at 156.

95. Id. at 157. 
totaled \$1,078,484, "while 3M's 1996 rebate to Sam's Club was $\$ 666,620$."96 $3 \mathrm{M}$ may not have willfully acquired power in the tape market, but these practices demonstrated willful maintenance of the monopoly power that they admitted to holding.

Applying the LePage's case to the group purchasing context and the exclusionary agreements that GPOs enter into with manufacturers, 3M's rebate structure utilized the strategy of product bundling to get purchasers to buy tape from $3 \mathrm{M}$ rather than its competitors. Giving buyers an incentive to purchase goods is not, by itself, a violation of the Sherman Act. But, here, 3M's actions to entice purchasers, while already holding a monopolist's share of the market, tipped the scales against them. The practice that $3 \mathrm{M}$ engaged in here is not unlike the exclusionary schemes that medical device manufacturers enter into with GPOs.

Group purchasing contracts with long-term, sole-source, and high requirements provisions are designed to secure and maintain market share. There can be no procompetitive business justification for using these contracting practices; binding market share for years to come and requiring that the purchaser not deal with any of the manufacturer's competitors can only be the actions of a want-to-be monopolist. While long-term, sole-source contracts with manufacturers do create a streamlined contracting process for GPOs, the efficiencies of utilizing this contracting scheme are far outweighed by the likelihood of resultant anticompetitive effects to market entrants and participants.

Administrative fees, discussed earlier in this paper, may also play a role in assisting manufacturers in moving towards protected monopolization in joint purchasing arrangements. In 2003, the GAO said that six out of the seven largest GPOs "reported that they have not negotiated any new or renewed contracts in 2003 that include administrative fees from medicalsurgical product manufacturers that exceed 3 percent." blem posed by the HHS regulation, which essentially allows GPOs to name their price as long as manufacturers agree to it, is that small manufacturers with fewer financial resources could be priced out of the market if the cost of entry became unaffordable. In essence, the manufacturer with the greatest financial resources in a relevant market could pay excessive administrative fees to GPOs in order to secure contracts with them, thereby buying monopoly power.

\section{Exclusive Dealing}

The final claim that a plaintiff manufacturer could bring, outside the group purchasing context, to challenge the contracting practices of competitor

96. Id.

97. GAO-03-998T, supra note 2, at 10; see supra note 23 for information about the $3 \%$ limit. 
manufacturers similar to those used by GPOs is a claim under section 3 of the Clayton Act. ${ }^{98}$ This section of the Clayton Act makes illegal contracts for the sale of goods "where the effect of such ... contract for sale ... may be to substantially lessen competition or tend to create a monopoly in any line of commerce." $"$ The Supreme Court has said that a plaintiff need not show that competition actually has been lessened by the exclusive dealing arrangement. ${ }^{100}$ Because some exclusive dealing clauses may serve a legitimate, procompetitive business purpose, courts examine challenges to these vertical restraints under the rule of reason analysis. ${ }^{101}$ The elements that a court will examine where there is an exclusive dealing arrangement are the following: the relevant market, the amount of that market that the arrangement has foreclosed to competing manufacturers, and any procompetitive reasons to justify keeping the arrangement in place. ${ }^{102}$

In 1982 when group purchasing arrangements were on the rise, a district court in White and White v. American Hospital Supply Corporation said that "[a] group prime vendor agreement which rises to the level of a group exclusive dealing arrangement would result in a substantial lessening of competition and a concomitant tendency towards monopolization in local distribution markets."103 The court went on to say that "a group purchasing agreement which suppresses competition in any local market where a member of the group is located violates the antitrust laws. To conclude otherwise is to permit group exclusive dealing contracts, which are not competitively bid, to establish local or regional monopolies."104

The dicta in this case is significant, because it demonstrates that as early as 1982 (before the antitrust safety zone was even created) there was a fear that group exclusive dealing agreements had the ability to suppress competition and produce monopolies. With the antitrust protection that the government affords GPOs under the current safety zone, market realities are beginning to reflect the district court's initial concern over exclusive dealing arrangements in White \& White. This is the state of affairs alleged by Applied Medical, the would-be plaintiff in my analysis, and the trend toward monopolies examined in the previous section seems to support that supposition as well. Exclusive-dealing, requirements, and long-term agreements that are

98. 15 U.S.C $\S 14$ (2005).

99. Id. (emphasis added).

100. Standard Oil Co. of Cal. v. United States, 337 U.S. 293, 311 (1949).

101. Chuck's Feed \& Seed Co. v. Ralston Purina Co., 810 F.2d 1289, 1294 (4th Cir. 1987).

102. Id. at 1295 .

103. White \& White, Inc. v. Am. Hosp. Supply Corp., 540 F. Supp. 951,1029 (W.D. Mich. 1982). This statement is only dicta within the court's opinion and is not the holding of the case. The case was later reversed on the grounds that the District Court did not properly define the geographic and product markets. In its reversing opinion, the Sixth Circuit Court of Appeals did not comment on the general legality of exclusive dealing agreements. White $\&$ White, Inc. v. Am. Hosp. Supply Corp., 723 F.2d 495 (6th Cir. 1983).

104. White \& White, Inc., 540 F. Supp. at 1029. 
used industry-wide have all of the ingredients necessary for substantially lessening competition in the relevant market.

A plaintiff, such as Applied Medical, will not have a difficult time defining the relevant market. The geographic market is generally a national one for medical devices and the product market varies depending on the level of sophistication of the medical device and the saturation of models in that market. ${ }^{105}$ The plaintiff will have a more difficult time showing whether the level of competition foreclosed by the exclusive dealing contracts constitutes a substantial share of the relevant market and rebutting the defendant's procompetitive justifications for utilizing exclusive dealing contracts.

There are two tests that courts use for determining whether exclusive dealing contracts have foreclosed a substantial share of market competition. There is a quantitative test and a qualitative test that courts apply. The landmark case of Standard Oil Co. v. United States ${ }^{106}$ laid the analytical foundation for the quantitative substantiality test. In that case, Standard Oil entered into exclusive dealing contracts with retail service-stations that covered $16 \%$ of the petroleum product market in the western state region. ${ }^{107}$ The Supreme Court considered whether $16 \%$ was a substantial enough percentage of the market foreclosed to violate the Clayton Act's exclusive dealing proscription. ${ }^{108}$ The court concludes that "Standard's use of the contracts creates just such a potential clog on competition as it was the purpose of section 3 to remove wherever, were it to become actual, it would impede a substantial amount of competitive activity." 109 In this case, $16 \%$ was enough market share to support a Clayton Act section 3 violation.

The alternative approach that courts have used is a qualitative analysis of whether exclusive dealing arrangements have foreclosed a substantial share of the relevant market. In Tampa Electric Co. v. Nashville Coal Co. ${ }^{110}$ the Supreme Court utilized this approach. The qualitative approach says:

[I]t is necessary to weigh the probable effect of the contract on the relevant area of effective competition, taking into account the relative strength of the parties, the proportionate volume of commerce involved in relation to the total volume of commerce in the relevant market area, and the probable immediate and future effects which pre-emption of that share of the market might have on effective competition therein. ${ }^{111}$

105. For example, the product market for q-tips may include cotton balls, but the product market for a specialized catheter may be more limited.

106. Standard Oil Co. of Cal. v. United States, 337 U.S. 293, 310-14 (1949).

107. Id. at 295-96.

108. Id. at 310-14.

109. Id. at 314.

110. Tampa Elec. Co. v. Nashville Coal Co., 365 U.S. 320,329 (1961).

111. Id. 
This approach utilizes a factual inquiry, where percentage of market foreclosure is only one factor in the analysis, as compared to the quantitative approach where a percentage is completely determinative of the substantiality of market foreclosure. In Tampa Electric, the court concluded that a requirements contract, which only foreclosed competition in less than $1 \%$ of the market, did not "tend to foreclose a substantial volume of competition." 12

In the absence of the safety zone, Applied Medical could succeed on the substantiality element of the Clayton section 3 claim under either test. 'Competitor manufacturers of trocars who enter into exclusive dealing arrangements with any of the major GPOs foreclose competition, but the deciding factor will be found in determining how much competition is foreclosed by those contracts. This determination will depend on the market share secured by each contract made. If one or two competitor manufacturers held exclusive dealing contracts with each of the seven major GPOs, then nearly $85 \%$ of the market for trocars would be bound. Based on the quantitative Standard Oil test, if $85 \%$ of the market were bound by exclusive dealing arrangements with only one or two manufacturers, then this would easily satisfy the substantiality requirement.

Under the qualitative Tampa Electric test with that same situation, the concentration of the trocar market that is bound by exclusive dealing arrangements would be a heavy factor; however, a court would also consider the strength of the competitor manufacturers as sellers and the effects that foreclosure of the market would have on competition. The percentage of the market bound by the exclusive dealing contracts alone suggests that the strength of the one or two competitor manufacturers who have entered into these arrangements is great. Applied Medical would be able to present, as evidence, its proposals to sell trocars at a $60 \%$ price reduction, which were rejected by the buyers involved in the agreements in question, to demonstrate the actual effects that market foreclosure is having on competition. Under this analysis, Applied Medical would succeed on qualitative substantiality.

If the market for trocars was less concentrated and involved several competitor manufacturers entering into exclusive dealing arrangements with individual GPOs, then the amount of market foreclosure secured by each individual contract would probably fall short under both tests. The largest GPO, Novation, only controls $\$ 19.6$ billion of the $\$ 190$ billion hospital purchasing market. If the trocar purchases by Novation's members were proportionate to that purchasing ratio, then a competitor manufacturer entering into an exclusive dealing arrangement with Novation would only foreclose just over $10 \%$ of the trocar market. Under the quantitative test, that may be enough to show substantiality, but under the qualitative test, it may not.

112. Id. at 335. This case is important solely for its application of a qualitative approach, because under the facts involved here, a quantitative analysis would have reached the same conclusion by the court. 
In Barr Laboratories, Inc. v. Abbott Laboratories, ${ }^{113}$ Barr alleged that contracts Abbott secured with "ten of the largest warehouse chain drugstores for the one-year period" to sell five types of adult erythromycin products violated section 3 of the Clayton Act. ${ }^{114}$ Barr argued that this arrangement satisfied the quantitative substantiality test of Standard Oil, because Abbott's agreements foreclosed $15 \%$ of the relevant market. ${ }^{115}$ In Barr Laboratories, both the district court and the Third Circuit looked instead to the qualitative substantiality test of Tampa Electric and agreed that the $15 \%$ "market preemption resulting from the contracts did not portend an immediate or future anticompetitive backlash."116 Based on the court's application of the substantiality test in Barr Laboratories, it is likely that the 10\% market foreclosure, which could be possible through an exclusive dealing arrangement with Novation, would not satisfy the qualitative or quantitative substantiality tests.

Finally, Applied Medical will have to rebut any procompetitive business justifications that its competitor manufacturers may have for entering into exclusive dealing arrangements. In Barr Laboratories, Abbott alleged price advantages, convenience, and business goodwill as procompetitive justifications for entering into the exclusive dealing arrangements. ${ }^{117}$ These justifications supported the court's conclusion that "the contracts at issue did not constitute impermissible exclusive dealing arrangements."118 Applied Medical's competitor manufacturers who have entered into exclusive dealing arrangements with GPOs could use efficiency justifications for their contracts with GPOs. Without the safety zone in place, efficiency concerns may be a heavy justification for Applied Medical to rebut. However, if Applied Medical could show that there has actually been a lessening of competition under the substantiality requirement, then legitimate business justifications may not be able to overcome that evidence.

Without the protection of the safety zone, Applied Medical would have solid footing in its claims against competitor manufacturers that have contracted with GPOs paying high administrative fees and using long-term, solesource requirements, and bundling contracts. With the safety zone in existence, however, the competitor manufacturers' potential violations of the antitrust laws are protected. When creating the antitrust safety zone, the purpose of the FTC and DOJ was to promote the economic efficiencies that group purchasing would yield. The agencies state that they will not challenge group purchasing arrangements that fall outside the safety zone which serve

113. Barr Lab., Inc. v. Abbott Labs., 978 F.2d 98 (3d Cir. 1992).

114. Id. at 104.

115. Compare this outcome to that of Standard Oil, where the market foreclosure was $16 \%$, and the Supreme Court held that $16 \%$ was enough to satisfy the substantiality requirement. Standard Oil Co. of Cal. v. United States, 337 U.S. 293, 295-96 (1949).

116. Barr Labs., Inc., 978 F.2d at 111.

117. Id.

118. Id. 
economic efficiencies unless there is a "substantial risk of anticompetitive effects." 119

One shortcoming of the enforcement policy that creates the safety zone for joint purchasing arrangements is that it discusses "entry barriers to forming new groups."120 The FTC and DOJ have looked at the group purchasing model only from the perspective of the buyer and the advantages that group purchasing provides for buyers. In that same context, the agencies also state that "if some competitors excluded from the arrangement are unable to compete effectively without access to the arrangement, and competition is thereby harmed, antitrust concerns will exist." 2121 The competitors that the agencies refer to here are the health care providers who are members of the GPOs. The current state of the safety zone enforcement policy is void of consideration for the impact antitrust protection will have on sellers that are trying to compete within the hospital supply area.

For over two years, the Senate, GAO, DOJ, and FTC studied several issues involving competition in the health care industry. The DOJ and FTC published a report concluding their review of the joint purchasing arrangement safety zone on July 23, 2004 ("the report"). ${ }^{122}$ The agencies determined that the GPO safety zone does not protect anticompetitive conduct and decided to leave the 1996 language of the safety zone intact. ${ }^{123}$ As a result, GPOs that currently use the contracting practices discussed herein will be free to continue using those practices with little fear of restriction.

The agencies failed to modify the safety zone to reflect its impact on sellers who must compete for group purchasing contracts. The example of Applied Medical illustrates the market realities of group purchasing and its potential to threaten market entry for sellers. In an industry where patients' lives depend upon the availability of life-saving devices, it is imperative for the safety zone not to provide GPOs with unfettered power over the medical device industry. With the protection of the safety zone, GPOs can assist large manufacturers in securing market share without limit by employing contracting arrangements that violate the antitrust laws outside of the group purchasing context. ${ }^{124}$

119. U.S. DEP'T OF JUSTICE \& FED. TRADE COMM., supra note 26, at 57.

120. Id. at 58 (emphasis added).

121. Id.

122. Press Release, Federal Trade Commission, FTC and DOJ Issue Report on Competition and Health Care (July 23, 2004), at http://www.ftc.gov/opa/2004/07/healthcarerpt.htm (last visited Apr. 16, 2005) (on file with the Indiana Health Law Review).

123. Id.

124. This is the case as long as each contracting GPO can meet the requirements of the safety zone. 
The report of the DOJ and FTC reviews the testimony and feedback that the agencies received in conducting their two year review of the safety zone. ${ }^{125}$ Yet, only two paragraphs of this nearly four-hundred page report address the agencies' conclusions about the future of the GPO safety zone after reviewing the available information on competition in the medical-supply industry. ${ }^{126}$ The overall conclusion of the agencies is that it would be impractical for Statement $7,{ }^{127}$ which created the GPO safety zone, to address all of the possible competition issues that could derive from the creation of a safe harbor. ${ }^{128}$ Therefore, the agencies conclude that when Statement 7 is silent on an activity (e.g., the use of exclusionary contracting practices), GPOs ought not to interpret that silence as legal endorsement for the activity. ${ }^{129}$

The agencies have effectively side-stepped addressing two years' worth of concerns about GPOs' contracting practices in their report. The report states that "[n]o statement is likely to cover every issue that could arise. The Agencies believe amending the statement to address some, but not all potential issues, is likely to be counterproductive." ${ }^{" 130}$ In addition, the report says that Statement 7 does not preclude agency or third-party initiated investigations of alleged abuses of the safety zone. ${ }^{131}$ In the context of tiering and pay-for-performance programs, the report says that the agencies will challenge "bundled contracting practices, where appropriate." 132 However, the report does not expressly outlaw any contracting activities and lacks clear rules defining improper activities under Statement 7.

As a result, the phenomenon discussed earlier in this article, where one manufacturer could hold individual contracts with the seven largest GPOsbinding nearly $85 \%$ of hospital purchases-without undergoing agency scrutiny, is still possible today. The only recourse available to a supplier that is denied entry to the marketplace under these circumstances is notifying the DOJ and FTC of the alleged violation. Consequently, the agencies might review that complaint. Nevertheless, the agencies have not established formal reporting or response systems to handle these violations.

If the safety zone forecloses antitrust enforcement (apart from the agencies' case-by-case review of complaints) as a remedy for manufacturers like Applied Medical, which has been closed out of the trocar market, then

125. U.S. DEP'T OF JUSTICE \& FED. TRADE COMM., IMPROVING HEALTH CARE: A DoSE OF COMPETITION 34-36 (July 2004), available at $\mathrm{http}: / / \mathrm{www} . f \mathrm{tc} . g o v / r e p o r t s /$ healthcare/040723 healthcarerpt.pdf.

126. Id. at 46 .

127. U.S. DEP'T OF JUSTICE \& FED. TRADE COMM., supra note 26, at 53-60.

128. U.S. DEP'T OF JUSTICE \& FED. TRADE COMM., supra note 125 , at 46 (stating that the report is also "silent on other potential competitive concerns, such as price-fixing, market allocation, mergers, etc.").

129. Id.

130. Id.

131. Id.

132. Id. at 47 (emphasis added). 
what recourse do the agencies or GPOs themselves have in dispelling concerns over current contracting practices?

\section{THE SAFETy ZONE's RoAD AHEAD}

Since the government's inquiries into GPOs and their contracting practices, many GPOs and the Health Industry Group Purchasing Association ("HIGPA") have issued codes of conduct which detail the principles that group purchasers will follow in doing business. Prompted by the government's hearings a few years ago, HIGPA established a "Code of Conduct Principles" to guide the GPO members of its trade association. This may be a step in the right direction, but HIGPA's code of conduct falls short of safeguarding the contracting process, because it fails to expressly restrict administrative fees, product bundling, or the combination use of long-term, solesource, requirements contracts. ${ }^{133}$ Following HIGPA's lead, Novation, the largest GPO, issued its own code of conduct on August 8, 2002. Novation's code makes participation in Novation-negoatiated contracts completely voluntary and not a condition of membership in the GPO. Its code also restricts contracts to terms of three years or less, restricts administrative fees to $3 \%$ or less, and rejects advance payments as part of a contract award. ${ }^{134}$

While Novation's code of conduct takes a firmer position on contracting practices than HIGPA's code, the common flaw in the codes of conduct industry-wide is that they are not legally enforceable regulations, but merely propositions for doing business. The codes of conduct are not binding on the GPOs who make or agree to follow them. Furthermore, "“[a]greements fixing prices and related terms of sales are unlawful per se." 135 If GPOs collude to establish restrictions on the terms of their sales, then those restrictions may be subject to antitrust challenge. ${ }^{136}$ As a result, the agencies are best positioned to establish clear and defined rules for permissible contracting practices.

The agencies' report falls short of remedying the potential market share foreclosure that confronts small medical device companies, like Applied Medical, today. In lieu of expanding Statement 7 to become an all-encom-

133. Health Indus. Purchasing Ass'N, Health Industry PURChasing Association CODE OF CONDUCT PRINCIPLES 5 (July 24, 2002), available at http://www.higpa.org/pressroom/2002/7-29HIGPACODE.pdf.

134. Press Release, Novation Commits to New Operating Principles to Enhance Value and Opportunities for Hospitals and Suppliers (August 8, 2002) (on file with Indiana Health Law Review).

135. Hospital Group Purchasing: Has the Market Become More Open to Competition: Before the Subcomm. on Antitrust, Competition Policy and Consumer Rights S. Comm. on Judiciary, at 2 (Sept. 26, 2003) (Statement of Robert Betz, Ph.D., President \& CEO, Health Industry Group Purchasing Association) (quoting Letter from Herbert Hovenkamp, Professor, Univ. of Iowa, College of Law, to HIGPA (June 21, 2002)) (emphasis added), at $\mathrm{http} / / /$ www.higpa.org/pdf/07-16-2003_testimony.pdf.

136. Id. at 3 . 
passing set of safe harbor rules, the agencies should issue formal guidance to the GPO and supply industries on appropriate contracting procedures. In addition, the agencies have enforcement authority among their powers to investigate and respond to anticompetitive contracting practices, in accordance with the case-by-case review process described in their 2004 report. This is necessary in order to close the loopholes for illegal tying, monopolization, attempted monopolization, and exclusive dealing, which Statement 7 and the report do not expressly prohibit.

As the law and the government's interpretations stand today, the safety zone is vulnerable to becoming a safe harbor for disguised anticompetitive conduct. The agencies' conclusion, that Statement 7's silence on prohibited contracting practices does not represent the government's blessing to engage in those practices, thoughtfully avoids the antitrust concerns that device companies spent over two years raising. Yet, current safety zone guidelines are completely devoid of the realities of GPO dealings. Statement 7 only addresses "horizontal agreements among hospitals to form a GPO."137 Statement 7 entirely lacks any information on the vertical arrangements into which GPOs, falling within the safety zone, may enter. In order to protect medical device manufacturers and ensure a competitive market for their products, the agencies need to reconsider the conclusions of their report and issue guidance to the supply industry or pursue enforcement of anticompetitive contracting practices.

\section{CONCLUSION}

GPOs may be threatening the competitive marketplace for medical devices and consumer access to affordable, quality devices. The safety zone from antitrust enforcement, created by the FTC and DOJ for joint purchasing arrangements, has both advanced and hindered the hospital supply area, particularly in the field of medical devices. The formation of GPOs has produced many transactional benefits, such as stream-lining the marketing process for manufacturers and negotiating discounts for their member providers that keep the cost of health care down for consumers. The group purchasing model coupled with an antitrust safety zone, while efficient horizontally, has vertical shortcomings demonstrated by the agreements that GPOs are making with manufacturers. Because joint purchasing arrangements that qualify for the safety zone are immune from antitrust enforcement absent extraordinary circumstances, GPOs can take advantage of the antitrust exemption by utilizing exclusionary contract terms, which but for the safety zone would violate the antitrust laws.

Exclusionary contracting practices jeopardize market share and market entry for medical device manufacturers. The agencies have fallen short on 
their promise to revisit the safety zone and address the concerns of those affected by current practices under the safe harbor. The agencies still have an opportunity to issue guidance to the supply industry or, even better, to take enforcement action against GPOs and large suppliers that engage in anticompetitive contracting practices. Life-saving medical devices are an integral part of the health care system, and the government must actively ensure that antitrust exemption does not deny manufacturers the ability to bring new devices and technologies to market. 
